\title{
Prevalence and intensity of Schistosoma haematobium among residents of Gwong and Kabong in Jos North Local Government Area, Plateau State, Nigeria
}

\author{
A. DAWET ${ }^{1 *}$, D.P. YAKUBU ${ }^{1}$, R. LONGMUT ${ }^{2}$, C.B. BENJAMIN ${ }^{1}$, \\ Y.H. DABURUM ${ }^{3}$ and N. NANNIM ${ }^{1}$ \\ ${ }^{I}$ Department of Zoology, Faculty of Natural Sciences, University of Jos, P.M.B. 2084, Jos, Nigeria. \\ ${ }^{2}$ Department of Family Medicine, Jos University Teaching Hospital, P.M.B. 2084, Jos, Nigeria. \\ ${ }^{3}$ Department of Biology, F.C.E. Pankshin, P.M.B. 27 Pankshin, Plateau State, Nigeria. \\ "Corresponding author, E-mail: dawetanthony@yahoo.com
}

\begin{abstract}
Schistosomiasis is a disease of great pathological effects in human especially during teenage years. The disease is a major public health problem with deepen economic consequences particularly in endemic areas. This study was conducted to determine the level of Schistosoma haematobium infection among the residence of Gwong and Kabong areas of Plateau State, Nigeria. Consent was obtained from the traditional heads and the subjects in the study areas. Ethical clearance was obtained from the ethical committee of Our Lady of Apostle (OLA) hospital Jos and Primary Health Care (PHC) clinics Nabor. A total of two hundred and forty two urine samples were collected and prepared using the sedimentation method. Slides were examined for $S$. haematobium ova under the microscope. Of all the samples examined, five $(2.07 \%)$ all from Gwong area were infected. Male had a higher prevalence $(3.85 \%)$ and mean intensity $(32 \pm 7.23)$ of ova compared with female. Infection was observed only in age groups 10-14 and 35-39 years. The prevalence was highest among those that obtained water from rivers/stream than those who used well water, while there was no infection among those that obtained water from borehole. The study showed that there was no significant difference $(\mathrm{P}>0.05)$ between infection and the study area, sex, age and occupation. However, there was a significant $(\mathrm{P}<0.05)$ relationship between the infection and their source of water. Though there was low to none prevalence and intensity of S. haematobium in Gwong and Kabong respectively, there is need to intensify integrated control measures to reduce or completely eradicate the disease.
\end{abstract}

(C) 2012 International Formulae Group. All rights reserved.

Keywords: Schistosoma haematobium, prevalence, intensity, Gwong, Kabong, Jos-Nigeria.

\section{INTRODUCTION}

Schistosomiasis (bilharzias or snail fever) is a human disease syndrome caused by infection from one of several species of parasitic trematodes (fluke) of the genus Schistosoma (WHO, 2012). It is second only to malaria in human impact among tropical diseases and the third (after malaria and intestinal helminthiasis) most devastating prevalent parasitic disease in the world, being a major source of morbidity and mortality for developing countries in Africa, South 
America, the Caribbean, the middle East and Asia (WHO, 2010a). According to (WHO, 2010b) more than 207 million people, 85\% who live in Africa, are infected with schistosomiasis and estimated 700 million people are at risk of infection in 76 countries where the disease is considered endemic, as their agricultural work, domestic chores and recreational activities expose them to infested water. Despite the complications that may occur, mortality appears to be low in that with 200 million cases, there are an estimated 14,000 deaths per year.

Schistosoma haematobium causes urinary schstosomiasis which results in substantial pathological effects in the bladder, ureter and kidney of infected individuals (Poggensee et al., 1999) and appendicitis (Doudier et al., 2004). Arinola and Salimonu (2003) reported that the untreated urinary schistosomiasis subject serum factor is inhibitory to leucocyte bactericidal activity. Percentage migratory index of leucocytes from apparently healthy subjects was reduced in the presence of pooled untreated urinary schistosomiasis subjects' serum.

Low prevalence $14(6.4 \%)$ infection of Schistosoma haematobium was reported out of 218 school children before treatment with praziquantel tablets in Langai community, Mangu LGA, Plateau State (Banwat et al., 2011). Joseph et al. (2010) reported an incidence of $110(14.5 \%)$ out of 744 pupils from 10 different primary schools in Maiduguri metropolitan council, while Ekpo et al. (2010) reported a higher prevalence 97 (58.1\%) of urinary schistosomiasis among 167 preschool children in a rural community near Abeokuta, Nigeria.

The increase in dams, reservoirs and other irrigation systems created by the Ministry of Agriculture and Water Resources through their water projects further increase the epidemiological factors in the study areas. The present study was conducted to determine the current status of urinary schistosomiasis among the residents of Gwong and Kabong communities in Jos North LGA, Plateau State, Nigeria.

\section{MATERIALS AND METHODS \\ Study area}

The study was conducted in Jos, Plateau State, Nigeria. Plateau State is located in the Northern Guinea Savanna vegetation belt, covering $8600 \mathrm{~km}^{2}$ with an average altitude of 1280 metres. It lies between latitude $9^{\circ} 55^{\prime} 07^{\prime}, \mathrm{N}$ and longitude $8^{\circ} 53^{\prime}$ 54 " E. The climate is semi-temperate with temperatures ranging from $18{ }^{\circ} \mathrm{C}\left(64.4{ }^{\circ} \mathrm{F}\right)$ to $25^{\circ} \mathrm{C}\left(77.0^{\circ} \mathrm{F}\right)$. The city of Jos receives about $1,400 \mathrm{~mm}$ (55.1 in) of rainfall annually.

The study was carried out in Gwong and Kabong Districts of Jos North Local Government Area of Plateau State, Nigeria with a total population of 429,300.

There are rivers and streams in the study sites. Laminga dam is located some kilometers away from Gwong where the people had contact with water for recreational activities. The residents of the study sites include farmers, students, civil servants, house wives and traders.

\section{Ethical clearance/study subjects}

Before the commencement of the study consent was obtained from the traditional heads of the areas. An official ethical clearance was obtained from the ethical committee of Our Lady of Apostle (OLA) hospital Jos and Primary Health Care (PHC) clinic Nabor Gwong where the samples were collected. People of the communities' were contacted and enlightened on the importance of the study through the assistance of the health workers, community and religious leaders. Volunteers in Kabong area were told to go to OLA hospital while those in Gwong to PHC clinic Nabor where their urine samples were collected. Information related to age, sex, occupation, source of water supply was obtained from each subjects. A total of two hundred and forty two comprising of seventy eight males and one hundred and sixty four females age zero to greater than fifty years were used in the study. 


\section{Collection of urine samples}

Urine samples were collected in May and June 2008 between 10 am and 1 pm after exercising before urinating which increases the number of eggs in the urine (Chandler and Read, 1961). A clean dry screw capped specimen bottle was given to each subject on the day of collection to avoid specimens outside the specified period. The bottles were labeled with corresponding numbers so the result would not be exchanged.

Subjects were instructed to include the last drops of urine, as these were known to contain the highest number of eggs (Cheesbrough, 1987). The samples were taken to the laboratory, Department of Zoology and OLA hospital for examination.

\section{Examination of urine}

The sedimentation method described by Olusegun et al. (2011) was used. 10-30 ml urine sample received from the subjects was thoroughly mixed after which a $10 \mathrm{ml}$ aliquot was transferred into a centrifuge tube and spun at $5000 \mathrm{rpm}$ for 5 minutes. The supernatant was decanted, while a drop of the sediment was placed on a clean grease free slide and covered with a cover slip and was examined under the microscope using the $\mathrm{x} 10$ and $\mathrm{x} 40$ objectives. The number of eggs were counted and recorded as eggs/10ml/urine.

\section{Statistical analysis}

Data obtained were analyzed using Chi-square test where $\mathrm{P}<0.05$ was considered significant.

\section{RESULTS}

Of the 242 subjects examined, $5(2.07 \%)$ were infected with Schistosoma haematabuim (Table 1). From the two areas, subjects from Gwong had the prevalence of $3.94 \%$ while there was no infection in subjects from Kabong. There was no significant difference $(\mathrm{P}>0.05)$ in the prevalence of urinary schistosomiasis between the two communities. Out of the five infected, three $(3.85 \%)$ were male while two $(1.22 \%)$ were females (Table 2). Statistical analysis showed that there was no significant difference $(\mathrm{P}>$ $0.05)$ in the prevalence of infection between males and females. The infection was showed in age group 10-14 and 35-39 (Table 3), with almost similar percentage infection $(4.88 \%$ and $4.17 \%$ respectively). The intensity was higher in age 10-14 with mean of $28.25 \pm 6.34$ ova/10 ml, while low quantity of $26 \mathrm{ova} / 10 \mathrm{ml}$ was observed in the only infected person of age 35-39. There was no significant difference $(\mathrm{P}>0.05)$ in the prevalence of infection according to age groups. The prevalence of infection in relation to occupation showed that student had the highest $4(3.70 \%)$ infection followed by house wives $1(2.17 \%$ ) (Table 4$)$. However, there was no significant difference $(\mathrm{P}>0.05)$ in the infection of $S$. haematobium between the occupational groups. The infection according to sources of water is showed in Table 5. A higher prevalence was observed among subjects that obtained their water from the streams $4(6.06 \%)$, followed by those that used well water $1(0.62 \%)$, while there was no infection among those that obtained water from bore hole. There was a significant difference $(\mathrm{P}<0.05)$ between $S$. haematobium infection and sources of water.

Table 1: Prevalence of Schistosoma haematobium among the inhabitants of Gwong and Kabong areas of Plateau State.

\begin{tabular}{lccc}
\hline Study area & Number examined & Number infected & Percentage infection \\
\hline Gwong & 127 & 5 & 3.94 \\
Kabong & 115 & 0 & 0.00 \\
Total & 242 & 5 & 2.07 \\
\hline \multicolumn{1}{c}{$x^{2}$ cal. $=3.819$} & $x^{2}$ tab. at df $1=3.841$ & P> 0.05 &
\end{tabular}


Table 2: Schistosoma haematobium infection among the inhabitants of Gwong and Kabong areas of Plateau State in relation to sex.

\begin{tabular}{lccc}
\hline Sex & Number examined & Number (\%) infected & $\begin{array}{c}\text { Mean egg count/10 } \\
\text { ml } \pm \text { SEM }\end{array}$ \\
\hline Female & 164 & $2(1.22)$ & $21.5 \pm 4.5$ \\
Male & 78 & $3(3.85)$ & $32 \pm 7.23$ \\
Total & 242 & $5(2.07)$ & $27.8 \pm 4.93$ \\
\hline \multicolumn{1}{r}{${ }^{2}$ cal. $=1.713$} & $x^{2}$ tab. at df $1=3.841$ & P> 0.05 & SEM= Standard error of the mean
\end{tabular}

Table 3: Prevalence Schistosoma haematobium among the inhabitants of Gwong and Kabong areas of Plateau State according to age.

\begin{tabular}{lccc}
\hline Age Group in years & Number examined & Number (\%) infected & $\begin{array}{c}\text { Mean egg count/10 } \\
\text { ml } \pm \text { SEM }\end{array}$ \\
\hline $0-4$ & 00 & 00 & 00 \\
$5-9$ & 00 & 00 & 00 \\
$10-14$ & 82 & $4(4.88)$ & $28.25 \pm 6.34$ \\
$15-19$ & 16 & 00 & 00 \\
$20-24$ & 12 & 00 & 00 \\
$25-29$ & 42 & 00 & 00 \\
$30-34$ & 39 & 00 & $26 \pm 00$ \\
$35-39$ & 24 & $1(4.17)$ & 00 \\
$40-44$ & 11 & 00 & 00 \\
$45-49$ & 14 & 00 & 00 \\
50 and above & 02 & 00 & $27.8 \pm 4.93$ \\
Total & 242 & P & SEM= Standard error of the mean
\end{tabular}


Table 4: Schistosoma haematobium infection amongst residence of Gwong and Kabong in relation to occupation.

\begin{tabular}{lccc}
\hline Occupation & Number examined & Number (\%) infected & $\begin{array}{c}\text { Mean egg count/10 } \\
\text { ml } \pm \text { SEM }\end{array}$ \\
\hline Civil servant & 20 & 00 & 00 \\
Farmer & 11 & 00 & 00 \\
House wives & 46 & $1(2.17)$ & $26 \pm 00$ \\
Student & 108 & $4(3.7)$ & $28.25 \pm 6.34$ \\
Trader (Business) & 57 & 00 & 00 \\
Total & 242 & $5(2.07)$ & $27.8 \pm 4.93$ \\
\hline$x^{2}$ cal. $=3.17$ & & &
\end{tabular}

Table 5: Prevalence of Schistosoma haematobium amongst residence of Gwong and Kabong in relation to their source of water.

\begin{tabular}{lccc}
\hline Source of water & Number examined & Number (\%) infected & $\begin{array}{c}\text { Mean egg count/10 } \\
\text { ml } \pm \text { SEM }\end{array}$ \\
\hline Borehole/ tap & 14 & 00 & 00 \\
River/ stream & 66 & $4(6.06)$ & $28.25 \pm 6.34$ \\
Well & 162 & $1(0.62)$ & $26 \pm 00$ \\
Total & 242 & $5(2.07)$ & $27.8 \pm 4.93$ \\
\hline${ }^{2}$ cal. $=6.73 \quad{ }^{2}$ tab. at df $2=5.991$ & $\mathrm{P}<0.05$ & SEM= Standard error of the mean
\end{tabular}

\section{DISCUSSION}

The low prevalence of $2.07 \%$ of Schistosoma haematobium observed in this study concurs with the $0.33 \%$ reported by Okpala et al. (2004) among pupils in Apata and Laranto areas in Jos. Akinboye et al. (2011) reported 5.5\% of urinary schistosomiasis among secondary schools students in Ibadan. Banwat et al. (2011) reported a prevalence of $6.4 \%$ in school children in Langai community, Mangu LGA of Plateau State. The low prevalence of $S$. haematobium in this study is not consistent with Ekpo et al. (2010) who reported 58.1\% prevalence among preschool children in a community near Abeokuta. Similarly Ugbomoiko et al. (2010) reported a prevalence of $62 \%$ in two peri-urban communities in South-Western Nigeria. Biu et al. (2009) reported a prevalence of $24.3 \%$ infection among school children in Konduga LGA, North Eastern Nigeria. The low prevalence of $S$. heamatobium observed in this study could probably be attributed to 
reduction in water contact activities which could have resulted from the availability of alternative sources of water and other recreational sites such as playgrounds. The low prevalence might be an indication of the level of awareness about the disease in the study areas. Health education is a very effective means of improving knowledge about urinary schistosomiasis and has the potential to reduce the prevalence of the disease (Jamda et al., 2007).

The prevalence of $2.07 \%$ observed in Gwong compared with the zero percent infection in Kabong could be attributed to closeness to open water sources and also being out-skirts of the city where some residents still disposed their stool indiscriminately. This agrees with KapitoTembo et al. (2009) who reported higher infection $(14.4 \%)$ in rural areas compared to the urban areas ( $3.6 \%$ ) in Blantyre, Malawi, and also that the location and proximity of school to open water source amongst other risk factors were significantly associated with urinary schistosomiasis infection. Subjects who lived close to the bodies of water or irrigation canals were more exposed and therefore more vulnerable to $S$. heamatobium infections than those who lived further from the water (Ugbomoiko et al., 2010; Abdullahi et al., 2011).

The insignificant prevalence and intensity of S. haematobium among sex group is consistent with Biu et al. (2009), Ugbomoiko et al. (2010), and Banwat et al. (2011). Deribe et al. (2011) reported a significantly high prevalence in males $61.7 \%$ compared to females $52.1 \%$ among Alsofia and Abuselala communities in south Darfur State, South western region of North Sudan. However, it varies with Ekpo et al. (2010), Nkegbe (2010) who separately reported insignificantly higher prevalence in female than male. The highest mean egg count recorded in male than female is consistent with Adeoye et al. (2008) who reported low level of infection of $<50$ eggs $/ 10 \mathrm{~m}$ in $73.8 \%$ of school children in Ibadan, Oyo- state, Nigeria. Ombugadu (2011) reported a highest mean egg count of $38.6 \mathrm{eggs} / 10 \mathrm{ml}$ in male than 18.2 eggs $/ 10 \mathrm{ml}$ in female. The mean intensity of eggs count in this study is at variance with Abubakar et al. (2006) who reported higher intensity of $13.5 \mathrm{eggs} / 10 \mathrm{ml}$ in female than $11.3 \mathrm{eggs} / 10 \mathrm{ml}$ observed in male. The higher prevalence and intensity observed among male compared with females could be attributed to the diverse outdoors activities engaged by males which exposed them to cercariae infected water.

The high prevalence among the age group 10-14 years in this study agrees with the finding of Dakul et al. (2001) who reported the highest prevalence $65.8 \%$ among the age group 10-14 years in Lankaku - Namu District, Quan'an pan LGA, Plateau State. Sarkinfada et al. (2009) reported the highest prevalence of $57.4 \%$ in age group 10-14 in Danjarima community, kumbotso LGA, Kano State, while no infection was observed in age group 35-39 years which varies with $4.17 \%$ observed among age group 35-39 years in the study. Joseph et al. (2010) and Akinboye et al. (2011) in their separate research reported higher prevalence of $15.0 \%$ in Maiduguri and $12.5 \%$ in Ibadan respectively among school children of age group 12-15 years. However, this result does not agree with Okoli et al. (2006) who reported the highest prevalence of $22.2 \%$ in the 21-30 years age cohort in Ohaji/ Egbema LGAs Imo state, Nigeria. In another study, Ombugadu (2001) reported the peak prevalence of $40.2 \%$ and $28.6 \%$ in male and female respectively between the age group of 21-25 years. The high prevalence and intensity in the age group 10-14 might be due to higher water contact activities of the boys and those within age group 10-14 years during outside activities such as errands, washing, and bathing/swimming.

The prevalence and intensity observed among school children and house wives could 
be attributed to frequent water contact since these groups engage in activities that involve frequent contact with water. The high prevalence of $S$. haematobium in school children recorded in this study agrees with Nmorsi et al. (2005) who reported $73.1 \%$ infection among school children in Ikpeshi Akoko-Edo LGA, Edo State. Ombugadu (2011) reported highest prevalence of $22 \%$ among those that engage in fishing, followed by farmers and student with $19.5 \%$ and $16.3 \%$ respectively among Udege community, Nasarawa LGA, Nasarawa State, Nigeria. This result opposed Olusegun et al. (2011) who reported the highest prevalence of $0.70 \%$ in artisan while there was no infection among students and house wife in HIV-positive patients attended the University of Benin Teaching Hospital Benin City Edo State, Nigeria. A high prevalence of $65 \%$ and $38.9 \%$ in fishermen and civil servant respectively was reported among school pupils in shelleng town, Adamawa state, Nigeria (Pukuma et al., 2006).

The high prevalence among those who obtained water from river/stream, followed by well is in agreement with Okpala et al. (2004) who reported $2.23 \%$ and $0.52 \%$ infection among school pupils who had their water from river/stream and well respectively. This contradicts Olusegun et al. (2011) who observed that all the $0.33 \%$ out of 2000 HIVpositive patients who were infected with urinary schistosomiasis had their water from bore hole. The high prevalence among those that used river/stream and well could be attributed to the openness of this water to sources of contamination. Some of the well were not always covered and children mostly seen fetching it without standard hygiene.

In conclusion there was low prevalence of schistosomiasis in the study area compared with studies in other areas. However, there should be constant surveillance of the disease to reduce if not possible to completely eliminate it. Safe drinking water and recreational activities should be provided in communities to reduce the rate of contact with infected water. Health education should be carried out in schools, community and other public gatherings to enlighten those that have not known and to remind those that might have forgotten about the epidemiology of the disease.

\section{ACKNOWLEDGEMENTS}

We thank the management of the Our Lady of Apostle Hospital and the health officers of Primary Health Care Nabor, Gwong for assistance during the collection of samples and the use of their facility. Thanks also go to the Department of Zoology for the use of her facility.

\section{REFERENCES}

Abdullahi MK, Bassey SE, Oyeyi TI. 2011. The epidemiology of Schistosoma haematobium infections in the 44 Local Government of Kano State, Nigeria. Nig. J. Parasit., 32(1): 19-24.

Abubakar U, Adamu T, Isiaku NT. 2006. Prevalence of urinary schistosomiasis among inhabitants of four localities of Wamakko Local Government of Sokoto State, Nigeria. Nig. J. Basic Applied Sci., 14(1-2): 23-27.

Adeoye GO, Thomas B. Magbagbeola OO. 2008. Epidemiology of Schistosoma haematobium in Ibadan South west area of Oyo State, Nigeria. The Trop. J. Health Sci., 15(1): 5-9.

Akinboye DO, Ajisebutu JU, Fawole O, Agbolade OM, Akinboye OO, Amosu AM, Atulomah NOS, Awodele O, Odola O, Owodunni BM, Rebecca SN, Falade M, Emem O. 2011. Urinary schistosomiasis: water contact frequency and infertility among secondary school students in Ibadan, Nigeria. The Nig. J. Parasit., 32(1): 129-134.

Arinola OG, Salimonu LS. 2003. Sera of some urinary schistosomiasis subjects 
affect migration and intracellular killing by leucocytes. J. Biomed. Invest., 1: 33-39.

Banwat ME, Daboer JC, Envuladu EA, Lar LA, Ogbonna CC. 2011. Effect of mass chemotherapy with praziquantel on the presence of schistosomiasis in school children in Langai community of Plateau State. J. Med. Trop., 13(2): 119-123.

Biu AA, Kolo AB, Agbadu ET. 2009. Prevalence of Schistosoma haematobium infection in school age children of Konduga Local Government Area, North eastern Nigeria. Int. J. Biomed. Health Sci., 5(4): 181-184.

Chandler AC, Read CP. 1961. Introduction to Parasitology. (Tenth edn). John Wiley and Sons Inc.: New York and London; 291.

Cheesbrough M. 1987. Medical Laboratory Manual for Tropical Countries. Low priced Edition Butter worth Heinemann Ltd; 321-329.

Dakul DA, Onwuliri COE, Anyanwu GI, Imandeh NG. 2001. A longitudinal study of Schistosoma haematobium infection in Qua'an-pan Local Government Area of Plateau State. J. Pest, Dis. Vec. Managt., 3: 225-230.

Deribe K, Eldaw A, Hadziabduli S, Kailie E, Omer MD, Mohammed AE, Jamshed T, Mohammed EA, Mergani A, Ali GA, Babikir K, Adem A, Hashim F. 2011. High prevalence of urinary schistosomiasis in two communities in South Darfur: Implication for interventions. Parasites and Vec. 4: 14doi:10.1186/1756-3305-4-14. 14http:/ /www.parasitesandvectors.com/content/4/ $1 / 14$.

Doudier B, Parola P, Dales JP, Brouqui P, Delmont J. 2004. Schistosomiasis as an unusual cause of appendicitis. Clin. Microbio. Inf., 10: 89.

Ekpo UF, Laja-Deile A, Oluwole AS, Samwobo SO, Mafiana CF. 2010. Urinary schistosomiasis among preschool children in a rural community near Abeokuta, Nigeria. http://www.parasites and vectors.com/content/3/1/58

Jamda AM, Ogbonna C, Zoakah IA, Daboer JC. 2007. Impact of health education on knowledge and practices of urinary schistosomiasis amongst children in Martin village. J. Med. Trop., 9(1): 21-27.

Joseph MB, Gaji B, Muhammad T, Baba MM, Thilza IB. 2010. Incidence of schistosomiasis in primary school pupils with particular reference to Schistosoma haematobium in Maiduguri. Researcher, 2(3): 31-36.

Kapito-Tembo AP, Mwapusa V, Meshnick SR, Samanyika Y, Banda D, Bowie C, Radke S. 2009. Prevalence distribution and risk factors for Schistosoma haematobium infection among school children in Blantyre, Malawi. PLoS Neglected Trop. Dis. 3(1):e361.doi: 10.1371/journal.pntd.0000361.

Nkegbe E. (2010) Sex prevalence of schistosomiasis among school children in five communities in the lower river Volta basin of South Eastern Ghana. Afr. J. Biomed. Research, 13: 87-88.

Nmorsi OPG, Egwunyenga OA, Ukwandu NCD, Nwokolo NQ. 2005. Urinary schistosomiasis in a rural community in Edo State, Nigeria: Eosinophiluria as a diagnostic marker. Afr. J. Biotech., 4(2): 283-186.

Okoli CG, Anosike JC, Iwuala MOE. 2006. Prevalence and distribution of urinary schistosomiasis in Ohaji / Egbema Local Government Area of Imo State, Nigeria. J. Am. Sci., 2(4): 46-49.

Okpala HO, Agba MI, Chimezie OR, Nwobu GO, Ohihoin AA. 2004. A survey of the prevalence of schistosomiassis among pupils in Apata and Laranto areas in Jos, Plateau State. J. Health Allied Sci., 1: 1-4. Olusegun AF, Ehis OC, Richard O. 2011. Proportion of urinary schistosomiasis 
among HIV-infected subjects in Benin City, Nigeria. Oman Med. J. 26(3): 175177.

Ombugadu RJ. 2011. A study of Schistosoma haematobium among the inhabitants of Udege community in Nasarawa Local Government Area of Nasarawa State, Nigeria. Biol. and Environ. Sci. J. Trop., 8(1): 81-84.

Poggensee G, Feldmeier H, Krantz I. 1999. Schistosomiasis of the female genital tract, public health performance. Parasit. Today, 15: 378-381.

Pukuma SM, Sale M, Njila HL, Dibal M. 2006. Urinary schistosomiasis in primary school pupils of Shelleng town, Adamawa State, Nig. J. Pest, Dis. Vector Managt., 7: 445-448.

Sarkinfada F, Oyebanji A, Sadiq IA, Ilyasu Z. 2009. Urinary schistosomiasis in the
Danjarima community in Kano, Nigeria. J. Inf. Dev. Ctries, 3(6): 452-457.

Ugbomoiko US, Ofoezie IE, Okoye IC, Heukelbach J. 2010. Factors associated with urinary schistosomiasis in two periurban communities in south-western Nigeria. Annals Trop. Med. Parasit., 104(5): 409-419.

WHO (World Health Organization). 2010 a. Schistosomiasis, Fact Sheet No 115. http://www.who.int/mediacentre/factsheet s/fs115/en/index.html.

WHO (World Health Organization). 2010 b. Weekly epidemiological record No 18 85: 157-164. http://www.whho.int/wer.

WHO (World Health Organization). 2012 Schistosomiasis. http://www.who.int/ topics/schistosomiasis/en/. 